\title{
How Does Male Readership Impact Character Portrayals in Contemporary Young Adult Adventure Novels?
}

\author{
Isabella Goncea ${ }^{1}$ and Denise Greenwood" ${ }^{1 \#}$ \\ ${ }^{1}$ Albright College, Reading, PA, USA \\ \#Advisor
}

\section{$\underline{\text { ABSTRACT }}$}

Adventure fiction has traditionally followed a male protagonist in their search for selfhood and saviorhood. In the case of contemporary adventure fiction, authors are likely to follow the conventions of the adventure story in order to fit the genre's stereotypes, which in turn reinforce gender stereotypes. This research paper discusses how contemporary young adult adventure novels typically perform within society's narrowly defined perception of male readership. While the novels attempt to perpetuate powerful female roles, the male characters fit the fantasy of traditional, male adventure stories. After analyzing traditional stories such as Paradise Lost and Beowulf and modern novels such as Harry Potter and Percy Jackson, I conclude that there are disparities between the portrayal of male and female characters: from the main hero to the minor characters to the antagonists, young adult adventure novels tend to follow traditional tropes in order to satisfy male readers. Even if the authors subvert the patriarchal tropes by adding female heroines or helpful minor characters, the overall work of literature creates a fantasy world that reinforces the traditional roles and desires expected of young boys. In time, these portrayals could encourage male readers to act patronizingly or dismissively toward girls and women.

\section{Introduction}

Adventure fiction has traditionally followed a male protagonist in their search for selfhood and saviorhood. As Eleanor Reeds asserts, adventure fiction uses a male character to represent young, real boys who need a positive example. The result, says Reed, is "commentators appear to agree on the genre's ability, whether threatening or welcome, to mold the goals and behavior of real boys" (70). In the case of contemporary adventure fiction, authors are still more likely to follow the conventions of the adventure story in order to fit the genre's stereotypes, which in turn reinforce gender stereotypes. While feminism, as we know it today, came to life in the late 1800 s, the common expectations of traditional adventure stories create a problem for contemporary young adult authors such as J.K. Rowling, Rick Riordan, and even more recent, Neal Shusterman and Rainbow Rowell. Although feminists work to deconstruct gender roles and give access to equal opportunities amongst all genders, adventure stories created a precedent of classic tropes that, even today, appeal to male readers more than other story plots and characters. According to the Canadian Council on Learning (CCL), "Boys frequently view reading as a feminine activity and this can reduce their motivation to read...Books about...adventure tales with male protagonists or natural events can alter boys' attitudes toward reading..." ("Why Boys" 5). Because of this notion of reading, authors are more likely to create characters that boys can connect to, thus we see the traditional tropes continue in contemporary young adult adventure novels. While authors attempt to include feminist ideals in their novels, they are limited by society's acceptance and expectance of conventionally masculine character types. 
As I will discuss in this research paper, contemporary young adult adventure novels typically perform within society's narrowly defined perception of male readership. While the novels include characters that perpetuate powerful female roles to match the male roles, the male characters ultimately fit the fantasy of traditional, male adventure stories. By choosing a random assortment of contemporary, YA Adventure series on Amazon's Best Sellers List, I was able to analyze how a variety of YA authors portray their characters. Furthermore, I choose both male and female authors to determine if / how often each gender perpetuates society's patriarchal views in their stories. By analyzing five specific character types - hero/heroine, sidekicks, victims, love interests, and antagonists - I cover the most important and influential characters of young adult adventures. In this case, after analyzing traditional stories such as Paradise Lost and Beowulf and contemporary novels such as Harry Potter, Percy Jackson, and The Hunger Games, I conclude that there are disparities between the portrayal of the young male and female characters.

After dissecting these adventure novels and their characters, I discover that young adult adventure novels tend to follow traditional tropes in order to satisfy male readers. By creating female heroines and minor characters that are generally weaker, less capable, and more emotionally unstable than their male counterparts, young adult novelists perpetuate the stereotypes of the tradition. Even if the authors subvert the patriarchal tropes by adding female heroines or less helpless side characters, the overall work of literature creates a fantasy world made to reinforce the traditional roles and desires expected of young boys.

\section{Male Versus Female Protagonists}

The frame of reference that young adult authors have is entirely male. In classical mythology, adventures are solely for male warriors such as Achilles, Odysseus, and Beowulf. In Beowulf, Beowulf fights monsters and receives help from other male characters, and there are almost no female interactions: "Beowulf searched out the bravest of the Geats, / asked them to go with him; that seasoned sailor / led fourteen thanes to the ship at the shore" (CrossleyHolland 79). Beowulf appeals to men's desires for travel and adventure while confining the women to the home. Additionally, the Old Testament, which contains numerous heroic stories similar to adventure, offers models such as Abraham, Isaac, Jacob, Moses, and the list goes on from there. As Eleanor Reeds asserts, "Although both boys and girls undoubtedly have constituted the readers of these books, it is the figure of the boy who has far more cultural resonance as a representative of a lost state [childhood]" (72). In other words, in order to reflect the same adventure story feel in young adult adventure novels, young adult authors feel the need to maintain male heroes. Furthermore, as Mykol Hamilton explains, even neutral terms have masculine connotations, otherwise known as "people = male" bias (393). This can also mean that "a male is more likely seen as a person than is a female" (393). Therefore, if an adventure novel protagonist is written as a heroine, male readers are less likely to be sympathetic and considerate of her struggles and choices within the adventure. Therefore, it becomes clear that authors of contemporary young adult literature choose to write their stories about a male protagonist because they feel it is necessary to appease male readers.

While most female characters/protagonists go through similar desires to know more about themselves and their lives, boys have almost always represented the desire to travel and find themselves through adventure. Rick Riordan, author of the Percy Jackson and the Olympians series, explains it best when he speaks about his inspiration for the character, Percy Jackson. Because Riordan's son, Haley, asked him to create his own mythological bedtime story, Riordan created Percy to inspire Haley, who also was diagnosed with ADHD and dyslexia. From there, Riordan realized that the story of young boys going on adventures was, historically, much more popular than a story of a female hero: "The idea of a young boy finding out he is special, training to use his abilities, and defeating an evil villain to take his rightful place in the world - this is the story of both Harry [Potter] and Percy [Jackson]. It's also the story of Perseus, Theseus, and Hercules - narratives that are over three thousand years old" (An Interview with Rick). Because these stories are told to boys from such a young age, they are more likely to pick a novel that has similar themes and characters. An experiment by Elizabeth Dutro reveals that "boys perform masculinities through their talk about their own and girls' reading preferences. All of their stated preferences center on sports and super-hero comics" (488). In 
order to stay relevant and popular with male readership that prefer stories about boys, sports, and adventures, young adult authors are more likely to follow the traditional stories with their corresponding traditional tropes.

Just as Rick Riordan created Percy Jackson to inspire young boys, J.K. Rowling wrote the Harry Potter series to connect with young audiences. As the CCL asserts, while young girls often read stories about both boys and girls, boys are much more likely to read when the story follows a male protagonist; even with a male protagonist, " $24 \%$ of Grade 2 boys view reading as feminine" (5). In order to convince her male readership that Harry Potter is for them, as well as for her female readership, J.K. Rowling uses her male protagonist, Harry Potter. She inspires young boys to read her novels because the series follows Harry in his battle against Voldemort from age eleven to age eighteen. Along the way Harry meets Ron Weasley, Hermione Granger, and Ginny Weasley. While Rowling includes several strong, able female characters in the Harry Potter universe, in keeping with generic expectations, the novels ultimately tell Harry's life story. Because society still follows a patriarchal hierarchy, Rowling chooses to write a story that appeals to boys' desires to read about adventures of other young boys.

Fortunately, while some authors find more success in using the traditional young male hero, other contemporary young adult authors have begun to subvert the patriarchal tropes by writing female heroes. For example, Neal Shusterman's Arc of a Scythe series follows both Rowan Damisch and Citra Terranova, respective male and female protagonists. Unfortunately, while these attempts are a step in the right direction, the authors still make decisions meant to appeal to a male audience. For example, although Shusterman writes about both Rowan and Citra, the series tends to focus more on Rowan's development into scythehood. Throughout the series, the audience learns much more about Rowan's emotional journey from innocent boy to heartless Scythe to passionate crusader. At the beginning of the series, Rowan is willing to fail his Vernal Conclave challenge in order to help Citra (Scythe 150151). By the middle of the first book, he already admits that he is capable of "[dialing] his conscience down to zero" in order to please Scythe Goddard. Although the story travels back and forth between Rowan and Citra's adventures, the readers do not see the same journey for Citra. As evidenced by the end of the first book, when Citra does show emotion, it is mostly for the changes she sees in Rowan:

At lunch, Citra - who still found she couldn't eat - watched from a distance as Rowan stuffed himself just as he had at breakfast, as if he had no care in the world. "He knows it's his last meal," a scythe she didn't know suggested. Although the woman was clearly showing her support for Citra, Citra found herself annoyed. "I can't see how it's any of your business." The scythe walked away, confused by Citra's hostility.

At this point in the novel, Rowan is still showing how "his heart had grown so cold, its fracturing could not hurt him anymore" (422). Although the audience has seen him change and will continue to see him grow in the next two installments, they only truly see Citra's growth in relation to Rowan's changes. While Shusterman tries to involve a female protagonist, she ultimately becomes the foil for Rowan, bringing him back from his emotionless state when he realizes how much he cares for her. Although her role is a very important one for the development of the series, it reminds the audience that the patriarchy is still strong; the male hero needs the women in his life for various reasons, but narratives such as the Arc of the Scythe series perpetuate an idea that the women will never be as important or independent as the men.

In a similar vein to Shusterman's attempts at creating a strong female protagonist, Cassandra Clare's The Mortal Instruments series follows Clary Fairchild, but Clary portrays characteristics that eventually make her a weaker character than her male counterparts. Although she shows strength when her mother disappears, Clary becomes the target of jokes because of her clumsiness and overall awkwardness: "Clary...was always tripping over her feet. The only time people turned to watch her go by was when she hurtled past them as she fell down the stairs" (City of Bones 36-37). While she is the daughter of two powerful Shadowhunters, Jocelyn Fairchild and Jonathan Morgenstern, nobody in The Mortal Instruments trusts Clary or takes her seriously; the audience especially sees how Jace feels about her in the third installment of the series:

You should never have come... The truth is that I don't want you here because you're rash and thoughtless and you'll mess everything up. It's just how you are. You're not careful, Clary...You're a disaster for us, 
Clary! You're a mundane - you'll always be one; you'll never be a Shadowhunter. You don't know how to think like we do, think about what's best for everyone - all you ever think about is yourself! But there's a war on now, or there will be, and I don't have the time or inclination to follow around after you, trying to make sure you don't get one of us killed! (City of Glass 122-123)

Although this confession comes from Jace's own stresses about keeping her and everyone else safe, it reflects many traditional beliefs that women do not belong outside of the house because they are a danger to men's goals. Because Clare is inspired by Paradise Lost, Dante's Inferno, and Mike Carey's Lucifer, she follows the patriarchal views of those texts (City of Bones Foreword). The idea that men look down on women begins with the Bible: "Likewise, ye husbands, dwell with [them] according to knowledge, giving honour unto the wife, as unto the weaker vessel" (The Bible, 1 Peter 3:7). Therefore, it comes as no surprise that Clare would write her characters in the same manner; the Bible essentially gives Clare permission to portray her female heroine as weaker than her male counterparts. Because Clare's inspiration comes from the Bible's representations of women and men, she elects to mimic these relationships to appeal to young male readers.

Opposite of Cassandra Clare's portrayal of Clary, Suzanne Collins's portrayal of Katniss Everdeen appeals to the male audience due to her more, evidently, masculine characteristics. Although she is visibly a young girl, when Katniss arrives at the Capitol, she must use archery skills to catch the Gamemakers' attention: "Suddenly I am furious...That I'm being upstaged by a dead pig. My heart starts to pound, I can feel my face burning. Without thinking, I pull an arrow from my quiver and send it straight at the Gamemakers' table... The arrow skewers the apple in the pig's mouth and pins it to the wall behind it" (The Hunger Games 101-102). Although Collins does not explicitly state that Katniss is more masculine, the fact that she is the only female character that uses archery suggests that Collins considers it to be a skill for boys. Even Katniss's response - the anger and need to prove herself - is reminiscent of male protagonists such as Harry Potter and Percy Jackson rather than characters such as Citra Terranova. Furthermore, her use of a bow and arrow to startle the rich Gamemakers recalls the traditional adventure stories of Robin Hood and William Tell. Robin Hood was most famous for using his bow and arrow to steal from the rich and give back to the poor ("Robin Hood"). Because Katniss lives in District 12, she has experience with being poor, and she holds a similar contempt for the rich as Robin Hood (The Hunger Games 4). William Tell was challenged to shoot an apple off of his son's head in order to overcome oppression by the Austrian government ("William Tell"). This mirrors Katniss's choice of using arrows to draw attention to herself and fight off the oppressive Capitol. While Katniss is a girl, these parallels between Katniss, Robin Hood, and William Tell inspires young boys to read the novel because she is more masculine than her female counterparts in the story.

Moreover, Collin's codes Katniss as masculine and / or male in the way that she steps into the traditionally male familial role of hunter after her father dies. Although she also gathers berries and nuts, she is the sole provider of the meat for her family because her sister and mother hold the more traditionally female roles. Both her sister and mother are shown to be nurturing in their medicinal practices and care for even the smallest of animals, such as Buttercup, Prim's kitten with a "mashed-in nose, half of one ear missing" (3). When Prim first brought Buttercup home to take care of, Katniss tried to drown him because "the last thing [she] needed was another mouth to feed" (3). Katniss does not have the same nurturing instincts as her mother and sister, so she is perceived as more masculine. While not all young girls are the same, so Katniss does not necessarily need to have the same caring instincts as her mother and sister, it calls into question why Katniss is the only girl in the series that does not have this same emotional connection with nature and animals. Although Collins strives to write about a strong, young girl, she ultimately suggests traditionally male tropes in her portrayal of Katniss in order to entice male readership.

While young girls are more likely to read about both male and female protagonists, boys are less likely to pick up a book unless they find characters that represent them, or at the very least, have similar interests as them. Consequently, in order to appeal to these readers, young adult adventure novelists typically choose to portray male heroes or masculine female heroines. Even as progress is made toward equal female and male characters, both historical and current societal expectations inherently encourage authors to write about characters that motivate young boys to choose their books. 


\section{Male Versus Female Secondary Characters}

While traditional adventure stories focus on the male character as the adventurer, the female secondary characters fall into one of three categories. In almost every adventure story, the female characters either become sidekick to the male protagonist, love interest to one of the male characters, or victim of the antagonist (they can also be a combination of these tropes). In Beowulf, while Beowulf has several quests to fight monsters, Wealhtheow stays away from the action, keeping her role as a hostess and passive mother: Wealhtheow came forward, / mindful of ceremonial - she was Hrothgar's queen; / adorned with gold, that proud woman / greeted the men in the hall, then offered the cup / to the Danish king first of all" (Crossley-Holland 89). Penelope from The Odyssey represents both the second and third trope: the love interest and the victim. Although Odysseus is gone for years, Penelope remains faithful to him by tricking her suitors into waiting for her to finish her tapestry. When the men become anxious and suspicious of her intentions, Odysseus must come to her rescue, fighting off the men and gaining her love again. Even hundreds of years later, novels such as Joseph Conrad's Heart of Darkness set the tone for how men and women should relate to adventure: "They - the women I mean - are out of it - should be out of it. We must help them to stay in that beautiful world of their own, lest ours gets worse" (44). It is adventure stories such as these that drive contemporary novelists to their portrayals of female characters in young adult adventure novels; because society looks to these stories as the norm, contemporary young adult authors are more likely to follow the tropes society has accepted.

\section{Best Friends / Sidekicks}

Just as Wealhtheow becomes a side character to Beowulf's adventuring, Hermione Granger, one of Harry Potter's best friends, is portrayed as a strong, intelligent young woman, but she is still overshadowed by Harry and Ron Weasley, Harry's other best friend. Even though she is noticeably smarter than both Harry and Ron, from the first novel, Harry Potter and the Sorcerer's Stone, Rowling creates a narrative in which Hermione must be saved by them. Ron, intimidated by Hermione's strength and intelligence, mocks Hermione to the point of her needing to isolate herself. After they save her, she defends them in front of Professors Snape and McGonagall: "If they hadn't found me, I'd be dead now...It was about to finish me off when they arrived" (178). Harry and Ron only begin to accept her when she shows loyalty to them, subordinating her role as a powerful young witch. As the novels progress, Hermione recognizes her subordinate role, recognizes that her male counterparts do not appreciate her strong personality, so she becomes much more vocal in her role as a protector of other characters that are constantly knocked down. As Rivka Kellner suggests, "Since house elves remind us so much of unemancipated women in chauvinist societies, it is no surprise that Hermione Granger, the central female protagonist...is bothered by the social injustices concerning the house elves..." (370). While Harry and Ron are supposed to support her attempts at social justice in the fourth novel, Harry Potter and the Goblet of Fire, they instead "basically [mock] Hermione's interest in improving [the house elves'] lot" (Kellner 370). The boys in the Harry Potter series do not truly appreciate Hermione for her intelligence because J.K. Rowling is following the tradition while also creating characters with whom young boys will connect. In order to inspire young boys to read, J.K. Rowling follows the tropes from the original adventure novels.

Just as J.K. Rowling creates a trio dynamic in Harry Potter, Rick Riordan's Percy Jackson and the Olympians series follows Percy Jackson and his best friends, Annabeth Chase and Grover Underwood. Similar to how Harry and Ron save Hermione in Harry Potter and the Sorcerer's Stone, Percy must go back to the bus to save Annabeth and Grover from the Furies, even though he is the least experienced fighter of the three (The Lightning Thief 164-169). One major difference between Harry's experience and Percy's is that both Annabeth and Grover get themselves into trouble in the first novel, whereas it is only Hermione in Harry Potter. While Hermione shows the most weakness throughout the rest of the novels as well, Annabeth and Grover seem to have similar experiences with getting into trouble and needing Percy to come help. Although they spend most of the series fighting right alongside him, they both have a novel dedicated to the trouble they get into. In the second installment, The Sea of Monsters, Grover gets 
stuck in Polyphemus's cave, and Percy and Annabeth must go to save him (73). This novel spends a lot of time building up the working dynamic between Percy and Annabeth. Unfortunately, the third book, The Titan's Curse, slightly undermines Annabeth's strength because she makes a mistake while fighting a manticore that leads to her disappearing for almost the whole novel (26). Similarly, while on the surface these two books seem to equalize the power dynamic between Annabeth and Grover, looking closer at The Sea of Monsters, the audience realizes that it reflects society's beliefs that women usually need more help. While it is Grover that is in trouble in the second novel, he spends most of it dressed as a cyclops bride in order to convince Polyphemus that he does not deserve to be eaten; when Percy and Annabeth find him, he is dressed as a woman and has fallen into the role of a caretaker and cook (74). Although they are saving Grover (the male sidekick), because he is dressed as a woman, Riordan reinforces the idea that young women need men to save them.

Novels such as Rainbow Rowell's Carry On, are actively working to reverse this patriarchal trope that women are not as powerful and intelligent as men. Because Carry On is meant to mimic the Harry Potter series, the audience sees the same dynamic between two boys and one girl, Simon, Baz, and Penelope. Unlike Harry and Ron, Simon and Baz admit that they cannot even function without Penelope there to tell them where to start (227). Baz even suggests Penelope is Simon's "smarter half" because he knows that Simon cannot be the Chosen One without Penelope by his side (227). Of course, this brings up a question about why Penelope is still seen as Simon's “half” (227). Instead of acting independently, she is still stuck in the role of best friend and sidekick because Carry On follows the precedent set by novels such as Harry Potter and Percy Jackson. Yet, as long as society continues to encourage young boys to read about other young boys, young adult authors will never truly escape the tropes.

While J.K. Rowling, Rick Riordan, and Rainbow Rowell write their stories about male heroes with female sidekicks, Cassandra Clare, in The Mortal Instruments series, takes a different approach by creating a dynamic in which Clary Fairchild has a male best friend / sidekick, Simon Lewis. Sadly, while this dynamic should help to subvert patriarchal tropes, Simon proves to be more helpful and powerful than Clary, even when he is incapacitated. Clare again falls victim to the traditional view in which men should have higher authority and power than women: "But I suffer not a woman to teach, nor to usurp authority over the man, but to be in silence" (1 Timothy 2:12). In City of Bones when Simon is transformed into a rat and kidnapped by vampires, Clary and Jace must go save him from the vampire den. Of course, they run into trouble when the vampires do not want them to leave, but Simon, human boy turned rat, is able to distract the vampires enough to point Clary and Jace in the right direction to escape (296). While Clary is meant to be a powerful Shadowhunter, Simon is actually more crucial to their escape as a rat. Simon continues to outshine Clary throughout the novel. When Simon shoots out the skylight to kill the demon in Clary's apartment, the group praises him, but he does not want the credit simply because he knew that the skylight was there. Clary also knew the skylight was there, but she did not think to do anything like Simon: "I knew it was there...I should have acted on it. Even if I didn't have a bow and arrow like Simon, I could have thrown something at it or told Jace about it. She felt stupid and useless and thick, as though her head was full of cotton" (City of Bones 381). While Clary, as the female protagonist, is supposed to rise to the occasion to help save her mother, she is constantly overshadowed by her male counterpart, Simon Lewis. Even though Clare writes Clary as the main character, Clary still falls victim to societal expectations in which the men are stronger and more capable.

Simon is not the only evidence of traditional views in Cassandra Clare's The Mortal Instruments series; the dynamic between Clary and Isabelle reinforces the patriarchal trope in which women cannot be friends because they are constantly fighting for attention, whether that be male or societal attention. Upon first meeting Isabelle, the audience realizes that she is powerful in her own right; she takes down a downworlder on her own before passing him off to Jace and Alec (City of Bones 20-21). But this powerful move is enough to start Clary's hatred for her. Because Isabelle is both powerful and beautiful, Clary begins to resent her: "She looked like a moon goddess. Clary hated her" (City of Bones 223). While it would make sense for them to stick together as the only girls in their group of Shadowhunters, Clare pits them against each other because society has convinced young adult authors and readers that is a normal relationship for two young women. It is not until Clary and Isabelle realize that they are not fighting for Jace's attention that they begin to warm up to each other. As Isabelle explains, “...I guess I resented you at first, 
but I realize now that was stupid. Just because I've never had a friend who was a girl doesn't mean I couldn't learn how to have one" (City of Bones 501). Although they seem to get along after this conversation, the first novel tends to set the tone for the rest of any series, so Clare has already reinforced the idea that young girls can only be friends after a young boy helps them realize that they are not fighting for the same attention.

While Cassandra Clare emphasizes the catty relationship between Clary and Isabelle, Collins emphasizes friendship and mutual respect with her portrayal of Katniss Everdeen and Rue. Rue quickly becomes an important side character, and although she is opposite of Katniss in how she uses her evidently feminine characteristics to survive, Katniss sees her as a sister and does everything in her power to protect her. On the other hand, because Rue is the counterpart to Katniss's more masculine characteristics, it is important to consider why Rue is written into the novel. She seems to represent Prim in the way that she uses her small stature to her advantage (184) and has a connection with animals, especially mockingjays (212). While this almost promises her a future in the series, Collins uses Katniss's affection for plot development. Collins kills Rue off quite quickly in order to motivate Katniss to win the Games. In this case, Rue falls into the same characterization as some female characters in traditional adventure stories. Instead of surviving until the end of the novel with Katniss, Rue dies because Katniss's arc relies on Rue's death. While the premise of the Games hints that every character must die except one, the fact that Katniss and Peeta both survive, and Rue does not - even though she and Katniss were working together first - suggests that Collins understands that love stories are more popular than stories about friendship.

\section{Helpless Victims}

While Hermione plays the role of a secondary character, Ginny Weasley, Ron's youngest sibling, and only sister, is dismissed as incapable of defending herself. When she is given a chance to go to Hogwarts herself, she creates chaos and falls into the role of needing a savior. Ron was able to defend himself in Sorcerer's Stone, at age eleven, but Ginny must be saved by Harry in Chamber of Secrets when she is eleven and the boys are twelve. Ron plays an extraordinary game of chess in the Sorcerer's Stone that allows Harry and Hermione to move on to finding the Stone before Professor Snape (actually Professor Quirrell): “Look, if you don't hurry up, he'll already have the Stone!... now, don't hang around once you've won" (283), he says. He allows the queen to knock him off the board in order to let Harry and Hermione move forward. In Chamber of Secrets, Ginny is the reason Voldemort is able to come back as Tom Riddle, even if it is just for the one novel. Since Rowling is writing an adventure novel, there is a religious undertone to Ginny's possession that follows the traditions of the Bible: "Just as Eve was deceived by a serpent, Ginny is deceived by the beguiling persona of Tom Riddle, who speaks to her through a magical diary...Deceived by the evil one, she is the cause of the fall - in this case, the opening of the deadly Chamber of Secrets" (Yeo $18^{1}$ ). Ginny falls into Eve's role as the fall of humanity, and therefore she relies on Harry to fix the problems. By the time Harry finds Ginny in the Chamber of Secrets, she has already collapsed, "white as marble, and as cold..." (307), and she does not wake up until after Harry uses the basilisk fang to destroy the diary (322). This is only the first novel in which Ginny truly has a role, so the audience does see her grow up to become less helpless, but Rowling eventually thrusts her into the role of love interest to Harry, so there is not much progress made for Ginny's character. Due to the classic "damsel-indistress" model of traditional stories, Rowling chooses to portray Ginny in a similar light.

Because J.K. Rowling's Harry Potter acts as a precedent to how contemporary young adult novelists write male and female relationships, it comes as no surprise that a novel such as Carry On involves a similar dynamic in which one of the female characters needs saving. As most of Rainbow Rowell's audience knows, Agatha Wellbelove is the parallel character to Rowling's Ginny Weasley. She begins as Simon Snow's love interest, but she later becomes the "damsel-in-distress" that young adult novels typically include. Similar to Rowling's Ginny Weasley, Agatha Wellbelove does have a redeeming arc in which she learns to save herself, but it is not without her first putting herself in the position to need to be saved. In fact, she does this so often that she admits herself, "That's how accustomed I

${ }^{1}$ This citation refers to the paragraph number instead of a page number. 
am to being rescued; I see a parade of people coming over the hill, and I assume they're coming to save me" (Wayward Son 320). That fact that she acknowledges her own cowardice is already an improvement from how Rowling handles Ginny Weasley's character. Furthermore, just a couple pages later, Agatha does come up with a plan to save herself and Penelope because she realizes that she cannot keep relying on others to do her bidding: "I lean forward and hold the flame over the front seat. It happens so fast. He burns so bright” (322). As even Penelope asserts, Agatha saves the day with her power. Agatha is no longer being held back by old notions that women are not as capable as men; she has taken a page from Penelope's book in order to prove to herself and her friends that she can take matters into her own hands. Similar to how Rainbow Rowell writes Penelope's character as a parallel to Hermione Granger, Rowell makes progress in her portrayal of Agatha Wellbelove as a parallel to Ginny Weasley. While she is still influenced by traditional adventure stories and Rowling's Harry Potter, Rowell shows that young adult authors can make simple changes to their stories in order to inspire young girls in the same way that most authors inspire young boys.

\section{Love Interests}

After Rowling takes Ginny Weasley out of the role of helpless victim, she turns Ginny into Harry's love interest instead of her own character. While Ron is Harry's best friend and so a secondary character, he is a boy and so goes through his own progression of finding love and gathering strength to fight alongside his best friends and family. However, Ginny only has a few moments of wisdom and wit until she is pushed aside because Harry wants to protect her from outside dangers. To be sure, in Half-Blood Prince, when Harry and Ginny first start dating, she makes jokes about Harry's "tattoo" and tells Ron off when he suggests that he gave her permission to date Harry: "Your permission,' scoffed Ginny. 'Since when did you give me permission to do anything?'” (536). She also has her own O.W.L.s to study for, so she is independent enough not to spend all of her time around her boyfriend and brother. However, this soon changes at the end of the novel. Although she seems to put up a fight when he first suggests that they should break up, she quickly agrees with him and lets him leave. When Harry explains that Voldemort uses people close to him, she argues, "What if I don't care?" (646). It seems like she is finally going to speak up about how he is going to look for the horcruxes with Ron and Hermione while she has to stay at school, but she quickly changes her mind: "Well... I can't say I'm surprised. I knew this would happen in the end. I knew you wouldn't be happy unless you were hunting Voldemort. Maybe that's why I like you so much" (647). All of the argument leaves her because she realizes that his fate involves fighting while hers requires she stay away. Whereas Ron and Hermione get to join in Harry's mission to defeat Voldemort, Ginny is left behind because she is meant to be Harry's love interest, needing his protection throughout the whole series. While Rowling gives Ginny small moments to shine, she ultimately casts Ginny into the role of a Penelope.

Although Rick Riordan gives Annabeth Chase more autonomy and action than Rowling gives Ginny Weasley, Annabeth moves from one crush to another throughout the Percy Jackson series. In the first novel, Annabeth portrays the classic signs of a crush on the older camper Luke Castellan: blushing, hyperventilating when he hugs her, etc (Lightning Thief 151). After Luke reveals himself as the camper working with the villain, Kronos, Annabeth's crush seemingly disappears, or as the audience discovers later, transitions from Luke to Percy. While she does not directly tell Percy until the second half of Percy Jackson and the Battle of the Labyrinth (when she kisses him), there are obvious signs in the beginning of the book when she is jealous of Percy's friendship with Rachel (16). She actually spends much of the novel making snarky remarks and displaying jealousy; it is not until the next novel, Percy Jackson and the Last Olympian, that Annabeth stops acting jealously toward Rachel. While Percy Jackson may reflect some reality of how young girls react to jealousy, stories that include these narratives can inherently and/or accidentally teach young readers, especially male readers, that this is how all young girls present themselves. Furthermore, while Riordan gives Annabeth many chances to prove herself worthy and capable of fighting alongside Percy, these lurking emotions tend to undermine her power. Instead of being able to separate her feelings from her actions, she allows petty emotions to guide her into belittling Rachel and pushing Percy away. Luckily, Riordan does give Annabeth an arc in which she can prove that she has control over some emotions. When they are given a chance to confront Kronos in 
Percy Jackson and the Last Olympian, Annabeth does not hesitate: "'YOU!' Annabeth turned on Luke. 'To think that I... that I thought...' She drew her knife...She attacked Kronos [in Luke's body], and his smug smile faded" (314). Because Annabeth takes the chance to attack her former crush, even after she admits to Percy that Luke was one of the only people she could trust, Riordan is setting an example for young readers of a powerful girl who embraces her emotions.

Unlike the previous series in which the main character is a boy, Neal Shusterman's Arc of a Scythe series follows both a boy and girl. Unfortunately, even though Citra and Rowan are both main characters, Shusterman still depicts Rowan as the protector and Citra as the love interest who needs protecting. Even from Citra and Rowan's first challenge during the Vernal Conclave, Rowan places himself in the position of worthier hero by pretending to be completely fearless (Scythe 150-151). Instead of admitting his worst fear to pass his challenge, he lies in order to put him on an even playing field with Citra. While he believes he is being noble and helpful, Citra becomes angry that he is bringing emotion into their contest: "'Maybe Scythe Curie will see what I did as noble,' Rowan [suggests]... 'Which proves,' Citra [says] to Rowan, 'that you're an idiot'" (151). Instead of appreciating his offer and continuing on the same path, Citra pits herself against Rowan, just as the rest of the Scythes have begun to do. This warring behavior continues until they finally unite and admit their love for each other at the end of the second installment: "When he took her in his arms, it suddenly didn't seem to matter what was going on outside of their tiny, sealed universe. In these terminal minutes of their current lives, it was just the two of them finally, finally giving in to their ultimate act of completion. The binary at last becoming the one" (Thunderhead 500). By creating this animosity between the two of them that actually represents and ends with their love for each other, Shusterman suggests to the audience that boys and girls cannot be friends, cannot help each other in times of need without there being an underlying reason. He reinforces the patriarchal trope in which women become the love interest to the hero. Even though Citra is determined to pit herself against Rowan, because the rest of the Scythes have already done the same, Rowan breaks down this type of relationship right from the beginning. Through Rowan's heroic behavior, Shusterman plays right into the adventure stories of the past.

Just as Shusterman attempts progress by including a girl main character alongside a boy, Cassandra Clare shifts the adventure novel so that Clary Fairchild is the main character in The Mortal Instruments series. Alas, as previously mentioned, Clary is treated as second string to almost every character in the series, especially Jace Herondale and Simon Lewis. Furthermore, she is not only secondary in her powers and abilities; from the first novel, Clary is placed into the role of love interest. First, Clary and Jace kiss after only knowing each other for a few days (City of Bones 334). Second, Jace puts Clary into the love interest role by comparing her beauty to Isabelle' s: "Isabelle used her beauty like she used her whip, but Clary didn't know she was beautiful at all. Maybe that was why" (343). He does not see her as fighter like he sees Isabelle; instead, he is determined to focus on Clary's beauty as a reason for why they would make a good couple. Lastly, Jace does not take Clary seriously whenever she discovers something important. As discussed earlier in the section about main characters, Jace is quick to dismiss her ideas, but this becomes a more prominent issue when he makes jokes about her art and intimacy: “'Jace,' she said. 'This is important.' 'Don't tell me,' he said. 'You've got a drawing emergency. You need a nude model. Well, I'm not in the mood...'” (City of Bones 344). Even though she explicitly tells him that she has something important to say, he makes jokes about nudity and drawing, essentially undermining her authority as a main character. Cassandra Clare's depictions of Jace and Clary speak to an audience that supports a "boys will be boys" mentality. Instead of acknowledging Clary's intelligence, Jace only thinks about beauty and sex because he does not see her as his equal, capable partner. While this may not be problematic on its own, because Jace does not suffer any true consequences except Clary yelling his name, Clare is perpetuating the idea that boys are allowed to treat girls like objects of desire. Because Jace does not learn his lesson - he continues to treat Clary poorly throughout the series - Clare underscores a narrative in which boys can treat girls patronizingly, which could ultimately encourage male readers to make similar choices when they are trying to begin a relationship.

Similar to Cassandra Clare, Suzanne Collins writes an adventure series from the perspective of a young girl whose life revolves around a boy. While Katniss Everdeen begins the Hunger Games series as an independent girl 
willing to sacrifice herself to the Hunger Games to ensure her sister's safety, the epilogue of Mockingjay undermines all of the autonomy and power Katniss had in the first two books. Instead of learning to love herself by herself, she relies on Peeta to make her feel whole:

But his arms are there to comfort me. And eventually his lips. On the night I feel that thing again, the hunger that overtook me on the beach, I know this would have happened anyway. That what I need to survive is not Gale's fire, kindled with rage and hatred. I have plenty of fire myself. What I need is the dandelion in the spring. The bright yellow that means rebirth instead of destruction. The promise that life can go on, no matter how bad our losses. That it can be good again. And only Peeta can give me that. So after, when he whispers, "You love me. Real or not real?" I tell him, "Real." (388)

The way Katniss switches her attention from one male character to another reveals an important pattern amongst young adult adventure novels. From Annabeth Chase's crushes on Luke and Percy to Clary Fairchild's relationships with Simon and Jace, young adventuring girls tend to rely on one or more male characters to make themselves feel safe and whole. Collins's choice of word, "need," underscores the message society sends to young girls about their relationship to the boys in their lives. Although Katniss is still very young by the end of Mockingjay (excluding the epilogue), she has chosen co-dependency rather than autonomy because society finds it satisfying to see her "completed" by being partnered. While they seem to have the pure love and friendship that Katniss deserves after so many years of suffering, the fact that she claims to "need" him reaffirms society's standard of girls relying on boys.

While authors such as Cassandra Clare and Suzanne Collins attempt to change the adventure story by creating young girl leads, Rainbow Rowell subverts the traditional story in which the young male hero fights the monster(s) and "wins" the young girl. In fact, in Rainbow Rowell's Carry On, Simon Snow's girlfriend at the beginning of the novel, Agatha Wellbelove, actually argues with Simon about this exact phenomenon when she breaks up with him: "What is our relationship? It is just me being there when you need a date to the ball? And crying for joy every time you come back from the dead?... I want to be someone's right now, Simon, not their happily ever after. I don't want to be the prize at the end. The thing you get if you beat all the bosses" (141). Because Rowell directly addresses this pattern in which the girl must wait until the end of the story to have a relationship, like a prize being won, she is reminding the audience that young girls are more than just the happily ever after of the adventure novel. Between Agatha's determination to be her own person and Penelope Bunce's single status, Rowell reinforces the changes that society is currently going through in acknowledging that girls have more to give to the world. Even Agatha's question in the middle of the novel helps young female readers realize their autonomous potential: "Why does everyone else think they know where I belong?” (199). While her adventure novel parallel, J.K. Rowling's Ginny Weasley, loses her autonomy because of her relationship with Harry Potter, Agatha sets out to be her own person. At the end of the novel, she actually leaves England for the United States in order to remove herself from the expectations and dangers of the wizarding world (497). Instead of relying on Simon, Baz, and Penelope to help her in the future, she leaves the country to prove her worth, and although she gets into a little bit of trouble in California, she is ultimately the one that saves herself. Rowell writes both Agatha and Penelope as independent girls who do not wait around for the boys in their lives to save them or show them love; in this way, Carry On shows progress towards a feminist society in which girls can achieve just as much as boys.

Whether the female characters are sidekicks, victims, or love interests, they are almost always portrayed as weaker and/or in less control of their emotions. If male readers are more likely to pick up books about male protagonists, it can be potentially harmful to perpetuate stereotypes in which the girls and women need men in order to survive or simply succeed in a mission. Unfortunately, as long as the tradition remains canon, and current society does not critique these authors for their mainstream choices, true progress can never be made.

\section{Male Versus Female Antagonists}

Traditional "positive" female roles refer to the roles that are directly secondary to the main character, but adventure stories tend to include undesirable females, as well. Sirens, or the mermaids of ancient Greek mythology, "[present] 
us with a discourse that associates female people with the irrational, with the sexual, with danger, with evil" (Cherland 278). Beyond sirens, the tradition introduces many "evil" female characters in the Christian narratives and Greek mythology. Lilith and Eve are seen as the first "transgressors" of humanity because they betray God's will. Although Lilith was created at the same time as Adam, Adam expects her to be subservient. When she refuses, God smites her by casting her out of Eden and replacing her with Eve. When Eve arrives, she agrees to be subservient to Adam, but she still betrays God and Adam by eating the apple. In Greek mythology Pandora is considered the "transgressor" because she opens up the box of sickness, death, and other evils. Even Beowulf, the first recorded Old English epic poem, includes Grendel's mother, a monster beyond compare to the other creatures Beowulf encounters: “...Grendel's mother acts aggressively, arguably in a fashion reserved for men. The similarity of her actions to that of her son, the fact that she is following in her son's (bloody) footsteps, is emphasized" (Acker 705). Grendel's mother is not even given a name because she is only known by her relationship with her son (Greenblatt 67). It comes as no surprise that stories such as Rick Riordan's Percy Jackson series would follow similar patterns. Just as traditional adventures villainize female characters, contemporary young adult authors portray girls and women as dangerous, specifically in their desire for the male characters.

J.K. Rowling sets the precedent for how contemporary young adult authors depict girls and women as antagonists to the male protagonists. When Rowling depicts a boy desiring a girl, she portrays it in a positive, almost childlike light. For example, when the Hogwarts boys first meet the Veela students, they cannot stop "goggling" and Ron even "[goes] purple" because he stops breathing" (Goblet 252). Every time there is mention of one of the boys having a crush on one of the girls, it is innocent and sweet; they almost never garner up enough courage to act on it, and if they do, such as Harry's kiss with Cho in Order of the Phoenix, it is a simple notion of interest. The girls and women of the Wizarding World seem to have a much different experience with desire. When Romilda Vane has a crush on Harry in Half-Blood Prince, she actually creates a love potion that Ron consumes through Chocolate Cauldrons she gave Harry for Christmas. Although it seems harmless, amortentia, the strongest love potion in the Wizarding World, is actually the cause behind Voldemort's birth and his inability to love, so therefore, it is clear that love potion can be dangerous when used inappropriately. While the boys in Harry Potter are innocent in their desires of girls, the girls are not as innocent.

Along with characters such as Romilda Vane, who is merely a Hogwarts student with a crush on a boy, Rowling also includes Bellatrix Lestrange, whose desire for Voldemort causes much of Harry's suffering in Order of the Phoenix, and of course, the story that started it all, Voldemort's mother, Merope Gaunt, who desired a muggle, Tom Riddle. Similar to the sirens from Greek mythology, both of these women's desires are villainized and used to move the plot of the novels. Even Bellatrix's name suggests violence; Merriam-Webster Dictionary explains that Bellatrix derives from the Latin "bellāre" which means "to wage war" ("Bellatrix"). It comes as no surprise that she is dangerous because of her desire to "wage war" on Harry Potter and please Voldemort. She kills Sirius and attacks Harry and his friends in the Department of Mysteries to get the prophecy for Voldemort (Order 806). Similarly, Merope Gaunt's desire for Tom Riddle begins the battle of Voldemort and Harry Potter; she creates amortentia to force Tom Riddle to marry and have children with her. The birth of Tom Marvolo Riddle, aka "I am Lord Voldemort," begins the story of Harry's parents' death and his battle against the most evil, powerful wizard in the Wizarding World (Chamber 314). Using a love potion, Merope compels Tom Riddle Sr. to marry her and father her child, so with no actual love involved in the union, Tom Riddle Jr. becomes the expression of lovelessness, incapable of love and compassion. Without compassion and love, Tom Riddle becomes Voldemort, the magical world's historically evil wizard. If Merope had let Tom Riddle Sr. walk away, a loveless Voldemort would not have been born to create the Harry Potter series. If Rowling had not been following traditional adventure novels, she might not have created Bellatrix and Merope. Just as Grendel's mother is the villain in Beowulf, Rowling makes Bellatrix and Merope villains for the Harry Potter series to follow tradition (Greenblatt 67).

Much like J.K. Rowling's Harry Potter series, Rick Riordan's Percy Jackson series follows a male protagonist that must deal with female antagonists, ranging from rather juvenile to extremely harmful. For example, Percy Jackson and the Lightning Thief begins with Nancy Bobofit throwing peanut butter sandwiches at Percy and 
Grover (3). While this is not necessarily a big deal, it sets a precedent for how young readers, especially boys, should view young girls. Similarly, later in the novel Riordan introduces Percy, and the audience, to Clarisse La Rue, a young daughter of Ares who puts Percy's head in a toilet (90). He even makes comments about Clarisse's weight, something for which society already judges young girls. By attributing her aggressive and antagonistic personality to her gender and weight, Riordan is underscoring society's beliefs that if young girls are not helpless victims incapable of handling themselves in tough situations, they are rude, aggressive, and potentially dangerous. There is no in-between in which the young girls can show emotions while still being considered the heroines. Fortunately, while the audience never sees progress for Nancy, Clarisse expresses a development in which she no longer feels the need to constantly belittle others. By making slow changes to Clarisse's personality, Riordan shows progress in showing young readers that girls are not defined by society's negative views of them. On the other hand, he continues to perpetuate gender standards in his portrayal of the villain from the second series, Gaia.

Just as Rick Riordan took most of his inspiration from Greek and Roman mythology, his portrayal of Gaia also has an undeniable parallel to the portrayal of Grendel's mother in Beowulf. Just as Grendel's mother proves to be a worse foe than her son, Gaia is overwhelmingly stronger and more dangerous than Kronos, the villain from the original Percy Jackson series. The Great Prophecy of the Percy Jackson series reveals that it will take only one demigod to defeat Kronos:

A half-blood of the eldest gods,

Shall reach sixteen against all odds,

And see the world in endless sleep,

The hero's soul, cursed blade shall reap.

A single choice shall end his days,

Olympus to preserve or raze. (The Last Olympian 55)

While Riordan reveals that Percy has some help from his friends and campmates, it is ultimately his fight against Kronos that ends the story and Kronos's reign. The same cannot be said for the Heroes of Olympus series; in fact, as Rachel Dare prophesizes at the end of the Percy Jackson series, it will take seven demigods to finally defeat Gaia:

Seven half-bloods shall answer the call.

To storm or fire, the world must fall.

An oath to keep with a final breath,

And foes bear arms to the Doors of Death. (The Last Olympian 368)

Throughout the Heroes of Olympus series, the audience discovers that Percy, Annabeth, Leo Valdez, Piper McLean, Jason Grace, Hazel Levesque, and Frank Zhang are all necessary pieces to the puzzle that will stop Gaia. Furthermore, it actually takes a deadly sacrifice in order for the seven of them to defeat her. Because gender roles from Greek and Roman mythology are passed down story by story, it is not difficult to see the parallel Rick Riordan has created between Grendel / Grendel's mother and Kronos / Gaia. Because young male readers are familiar with the European myths they are taught in school, they are more likely to choose stories that reflect those same tropes. Therefore, young adult authors such as Rick Riordan choose to write about the gendered tropes of the tradition.

While Rick Riordan got his inspiration from Greek mythology and epic poems such as Beowulf, Cassandra Clare takes inspiration from the Christian mythology in order to create chaos in The Mortal Instruments series. Cassandra Clare admits her fascination with the older stories in the Foreword of City of Bones:

When I set out to write City of Bones, I was in love with stories about vampires and faeries and warlocks, but I was also in love with the mythological tales of angels and demons. I was fascinated by Paradise Lost and Dante's Inferno and Mike Carey's Lucifer. I was fascinated with the way that human beings had grappled with the ideas of absolute evil and absolute good tempered with love and free will. (Foreword ${ }^{2}$ )

She exposes the types of characters she set out to create; her attraction to Paradise Lost reveals why she would create a character such as Clary Fairchild. Just as Eve is overshadowed by Adam's perfect nature in Paradise Lost, Clary is

${ }^{2}$ The Foreword does not have page numbers, but it is located right at the beginning of the first novel, City of Bones 
constantly overshadowed by Jace Herondale and Simon Lewis. Similarly to how Paradise Lost's Eve and J.K. Rowling's Ginny Weasley both wreak havoc because of temptation, Clary causes more problems than she solves because of her connections with Simon, Jace, and her father (the villain of The Mortal Instruments series). Just as Jace points out in City of Glass, Clary has a habit of ruining plans because she spends more time trying to prove to the men in her life that she is capable than doing what it takes to actually prove it (122). If she were to ignore the temptations of relationships (with both Jace and Simon), she might have proved herself worthy by doing rather than simply listening. Because she is constantly distracted by them, it actually takes her much longer to solve problems. In the first novel, City of Bones, Clary is only able to figure out where her mom hid the goblet when she removes herself from the temptations of Jace; ultimately, Clary must dig herself out of the hole of temptation in order to be productive (344). Eventually it becomes clear that while Clare attempts to give Clary her own heroine story and make her the problemsolver, she actually puts Clary in the role of problem-maker.

While the novels from the early $21^{\text {st }}$ century prove to be works in progress toward true equality and fair representation of men and women, Neal Shusterman's Arc of a Scythe series seems to do the best with subverting gender roles in media. Although it may initially seem like he is perpetuating the same tropes with his portrayal of Scythe Rand, Shusterman's novels comment on society's perceptions of women through his depictions of Scythe Curie. Originally, Scythe Rand seems like the classic predatory female that develops throughout history: "Scythe Rand constantly slapped his glutes, threatening all sorts of lewd liaisons with him once he was of age" (Scythe 242). Similar to Grendel's mother, Gaia, Bellatrix Lestrange, etc., Scythe Rand's desires are predatory, dangerous, and potentially deadly; the audience learns that Rand "gleans for sport - for the joy of it...because [she] can" (263). Her male counterpart, Scythe Volta, actually shows more emotion and empathy towards his gleaning victims, even though he is part of her same inner circle of Scythes (267). Fortunately, while Shusterman makes Scythe Rand out to be an almost irredeemable villain in the first novel, she does not represent all of the women in the series. In fact, Shusterman uses Scythe Curie to comment on how society tends to perceive women as evil even when they do less harm than men. Although Scythe Curie learned to glean from Scythe Faraday, the Scythe society begins calling her names such as "Miss Massacre" and "the Grande Dame of Death" (273). By including this parallel between Scythe Curie and Scythe Rand, Shusterman underscores how impactful society's views of women have been and will be for the foreseeable future. By creating a predatory female while simultaneously explaining how society makes women out to be villains when they are not, Shusterman encourages the audience to question gender roles and tropes from the past. He understands the importance of discussing sexism and gender issues in media, and he has chosen his young adult novels to do just that.

Young adult adventure novelists tend to choose adventure tropes and plotlines that intrigue both male and female readers. Since many young readers are taught about Greek and Roman mythology, and stories such as Beowulf, in their middle school and high school classes, they are more likely to choose novels with similar storylines when they read for pleasure. In the case of the above novels, the authors wrote about female villains because they reflect the traditional stories readers learn about in childhood. In order to remain relevant authors, young adult adventure novelists feel the need to write about what their audiences know already.

\section{Conclusion}

As the above study suggests, young adult adventure novelists typically follow traditional tropes and storylines in order to appeal to their young adult audiences, especially the male readers. According to the Canadian Council on Learning, "a recent study in the United States found that the genres preferred by boys were available in only one-third of classrooms" ("Why Boys" 4). When the topics considered appropriate for classrooms typically pertain to adventure stories such as the Greek myth of Odysseus or the Germanic myth of Beowulf, it is not surprising that young boys are more likely to pick up and read stories with similar themes and characters when they are outside of the classroom. If they are not taught about other types of stories, they will gravitate towards the stories with which they are familiar. Furthermore, boys are more likely to identify with the men in their lives, and men, in general, do not read as many 
books as women (Sullivan 36). Therefore, if they are only ever exposed to stories in the classroom, particularly adventure stories, it can be assumed that they will pick those up outside of the classroom. Due to this, young adult authors decide to write about male and female characters with the same characteristics as the traditional stories.

Unfortunately, because authors are using the traditional tropes to remain relevant, they perpetuate the stereotypical maleness of the adventure stories of the past. Although authors are not required to write with a feminist viewpoint, there is much to be said about the influence of young adult novelists who believe in equality and use their novels to comment on society. Because adolescents tend to be more receptive to new ideas, young adult authors are more likely to have success in convincing their readers that everyone deserves equality and proper treatment. In order for young adult authors to be able to truly subvert the patriarchal tropes, society would have to change its insistence upon the patriarchy, specifically the relationship between men and women. Because this may take a long time, it is important that authors begin to change the way they depict women and girls in their novels. Thus, the cycle begins.

Because other forms of media are such influential tactics for social change nowadays, for girls and women to ever have a chance of being seen as equal to their male counterparts, young adult novelists would need to write about female characters that succeed in the same ways as the male characters. On the other hand, because male readers are less likely to choose books that are not framed around a masculine narrative, authors will probably never have the true impact they wish to have. Fortunately, there are authors working toward a feminist society right now, even with the social barriers; novelists such as Neal Shusterman and Rainbow Rowell write every day in order to prove to society that everyone deserves to be treated and represented fairly both in real life and in media. While they may include certain stereotypical characters and themes in order to attract readership of all genders, they are still doing their parts to represent different people and stories. It is my hope for the future that novelists begin or continue to consider their influence when they write adventure stories based in the historical tradition of adventure stories.

Finally, I believe that this research can be improved by considering the biases of our statistically white, cisgender, heteronormative society. While my research does include Neal Shusterman's Arc of a Scythe series, the rest of the series on the Amazon Best Sellers List are written by white authors for majority white audiences. If I were to recreate or expand on this study, I would include more diverse authors and characters in order to determine if those stories also perpetuate white, patriarchal society. Furthermore, this study focuses on the young characters because, unlike adult and general fiction, YA novels do not typically revolve around the adult figures in the young characters' lives; therefore, I do not study any of those older characters in this paper, unless they fit into the antagonist role. If I were to advance this study, I would research the roles the father and mother figures have to discern if the patriarchal tropes continue with them. Lastly, in order to include diverse family structures, I would study more novels that include characters within the LGBTQ+ community, rather than just Rainbow Rowell's Simon Snow series. In order to make social change, it is our duty as readers and researchers to also include diverse and complex stories in our daily lives. By expanding on this research, I would be able to contribute in diversifying our bookshelves and lives.

\section{References}

Acker, Paul. "Horror and the Maternal in 'Beowulf.'” PMLA, vol. 121, no. 3, 2006, pp. 702-16. JSTOR, Www.jstor.org/stable/25486349. Accessed 8 Dec. 2020.

“An Interview With Rick: Rick Riordan.” Rick Riordan | Welcome to the Online World of Rick Riordan, 17 Jan. 2021, rickriordan.com/about/an-interview-with-rick/.

"Bellatrix." Merriam-Webster.com Dictionary, Merriam-Webster, https://www.merriamwebster.com/dictionary/Bellatrix. Accessed 16 Apr. 2021.

Cherland, Meredith. "Harry's Girls: Harry Potter and the Discourse of Gender." Journal of Adolescent \& Adult Literacy, vol. 52, no. 4, 2008, pp. 273-82. JSTOR, www.jstor.org/stable/40058129. Accessed 21 Feb. 2020.

Clare, Cassandra. City of Bones. Walker Books, 2015.

---. City of Glass. Walker Books, 2015.

Collins, Suzanne. Mockingjay. Scholastic Press, 2010. 


\section{Journal of Student Research}

---. The Hunger Games. Scholastic Press, 2008.

Conrad, Joseph. Heart of Darkness. 2020, https://www.planetebook.com/free-ebooks/heart-of darkness.pdf.

Crossley-Holland, Kevin, translator. The Anglo-Saxon World: An Anthology. Oxford University Press, 2009.

Dutro, Elizabeth. "'Us Boys like to Read Football and Boy Stuff': Reading Masculinities, Performing Boyhood.” Journal of Literacy Research, vol. 34, no. 4, Dec. 2002, pp. 465-500, doi:10.1207/s15548430jlr3404_4.

Greenblatt, Stephen, and M. H. Abrams, editors. The Norton Anthology of English Literature. 8th ed., vol. 1, W.W. Norton \& Company, Inc., 2006.

Hamilton, Mykol C. "Masculine Bias in the Attribution of Personhood: People = Male, Male = People." Psychology of Women Quarterly, vol. 15, no. 3, Nov. 1991, pp. 393-402, doi:10.1111/j.1471-6402.1991.tb00415.x.

Kellner, Rivka Temima. “J. K. Rowling's Ambivalence Towards Feminism: House Elves -Women in Disguise - in the 'Harry Potter' Books." Midwest Quarterly: A Journal of Contemporary Thought, vol. 51, no. 4, 2010, pp. 367-85. EBSCOhost, search.ebscohost.com/login.aspx?direct $=$ true $\& d b=m z h \& A N=2018700675 \&$ site $=$ ehost-live.

Reeds, Eleanor. "Transatlantic Elegies for Boyhood: First-Person Adventure Narratives after 1865." Lion and the Unicorn: A Critical Journal of Children's Literature, vol. 41, no. 1, Jan. 2017, pp. 61-78. EBSCOhost, search.ebscohost.com/login.aspx?direct=true \&db=mzh\&AN=2017308136\&site=ehost-live.

Riordan, Rick. Percy Jackson and the Battle of the Labyrinth. Scholastic Inc., 2009.

---. Percy Jackson and the Last Olympia. Scholastic Inc., 2010.

---. Percy Jackson and the Lightning Thief. Scholastic Inc., 2006.

---. Percy Jackson and the Sea of Monsters. Scholastic Inc., 2007.

---. Percy Jackson and the Titan's Curse. Scholastic Inc., 2008.

"Robin Hood." Edited by Adam Augustyn, Encyclopaedia Britannica, Encyclopædia Britannica, Inc., 2019, www.britannica.com/topic/Robin-Hood.

Rowell, Rainbow. Carry On. St. Martin's Press, 2017.

---. Wayward Son. St. Martin's Press, 2019.

Rowling, J.K. Harry Potter and the Chamber of Secrets. Scholastic Inc., 1998.

---. Harry Potter and the Goblet of Fire. Scholastic Inc., 2000.

---. Harry Potter and the Half-Blood Prince. Scholastic Inc., 2005.

---. Harry Potter and the Order of the Phoenix. Scholastic Inc., 2003.

---. Harry Potter and the Sorcerer's Stone. Scholastic Inc., 1997.

Shusterman, Neal. Scythe. Simon \& Schuster BFYR, 2017.

---. Thunderhead. Simon \& Schuster BFYR, 2019.

Sullivan, Michael. "Why Johnny Won't Read: Schools Often Dismiss What Boys Like. No Wonder They're Not Wild About Reading.” School Library Journal, vol. 50, no. 8, Aug. 2004, 36.

The Bible. Authorized King James Version, Oxford UP, 1998.

"Why Boys Don't Like to Read: Gender Differences in Reading Achievement." Canadian Council on Learning, 2009, pp. 1-8.

“William Tell.” Edited by Kathleen Kuiper, Encyclopadia Britannica, Encyclopædia Britannica, Inc., 2021, www.britannica.com/topic/William-Tell.

Yeo, Michelle. "Harry Potter and the Chamber of Secrets: Feminist Interpretations/Jungian Dreams." Simile: Studies in Media \& Information Literacy Education, vol. 4, no. 1, Feb. 2004. EBSCOhost, doi:10.3138/sim.4.1.002. 